\title{
Implication of Output Hypothesis on Teaching College English Writing
}

\author{
------Based on an interview in JiangXi Normal University
}

\author{
Honglan Wei ${ }^{1, *}$ \\ ${ }^{1}$ Foreign Languages College, JiangXi Normal University, Nan Chang, China \\ *Correspondence: Foreign Languages College, JiangXi Normal University, Nan Chang, China. E-mail: \\ 1342662169@qq.com
}

Received: September 23, 2018 Accepted: October 18, 2018 Online Published: October 25, 2018

doi:10.5430/wje.v8n5p198

URL: https://doi.org/10.5430/wje.v8n5p198

\begin{abstract}
In recent years, with the development of the research on the Output Hypothesis, many researchers and Chinese English teachers have paid attention to this hypothesis. Since writing is considered to be a way of output on the field of second language acquisition, teachers in college have begun to apply Swain's "Output Hypothesis" to teaching college English writing. It does work but still remains problems. Therefore, this paper will introduce the existing problems of applying the output hypothesis on the writing class in our college, based on the interview by interviewing six seniors majoring in English from different classes in our Foreign Language College. Also, this paper will provide some suggestions on these problems existing in teaching college English writing.
\end{abstract}

Keywords: output hypothesis; English writing; second language acquisition

\section{Introduction}

\subsection{Background}

Resent years have witnessed a steady increase of importance on English teaching. However, most English teaching classes have focused too much on the students' input abilities, more specifically, listening and reading, while speaking and writing as output abilities are ignored. In the practice of English teaching in the university, it can be obviously noticed that writing is the weakest part among the whole English major students(Jia Na,2007). As we all know, in the traditional English teaching classes, teachers just are excellent knowledge presenters as they are always prepared to explain every details to the students. And students actually enjoy this kind of class because they do not need to search any learning materials and just instill the knowledge from the teachers.

In fact, writing class in college is also the case. Students in the class just listen all the writing skills told by the teacher. On the class, they listen carefully and nod all the time, but after the class, they actually do not know how to write a composition. So, English writing, as a way of output, is much more difficult than other classes such as reading and listening classes. Due to this serious situation, college English teachers are supposed to get a better and more efficient way to improve students’ English writing abilities.

\subsection{Significance of the Study}

In this paper, it presents the existing problems in the college English writing class. These problems are concluded through an interview by asking 20 students some related questions. These students are all seniors in different classes from our Foreign Language College. They are called student A,B,C... in the following part. The writing teachers are called YHL,FD,CYC,JLM,ZXY,MHH(the first letter of the names). By asking teachers some relevant questions, we can get some facts about writing classes in our college. This helps us to conclude the existing problems on English writing class. Furthermore, it enables us to get some implication of Output Hypothesis on college English writing.

With the reform movement in education, greater attention has been paid to the teaching of the English language. The ability to write is recognized in society and in the schools as one of the most important objectives of language learning. At the same time, with the greater demands of English ability, writing ability is higher than before. However, most of the college students do not get satisfying results. According to Swain,” output pushes learners to process language more deeply with more mental effort than input...Students' meaningful production of language would seem to have a potentially significant role in language development”(Swain,2000)and may force the learners 
to move from semantic processing to syntactic processing”(Swain,1985). Therefore, this study intends to address two research questions:

1. What are the drawbacks of college English writing class in China?

2. What suggestions can we get from this study on teaching college English writing in the future?

\section{Literature Review}

\subsection{General Background and Definition of Output Hypothesis}

In the early 1980s, the burgeoning field of SLA was dominated by the concept of "input hypothesis" of Krashen, which was widely accepted and gradually adopted into teaching. However, the successive researchers have found, compared with the native speakers, the learners are far from these native speakers in utterance and writing. Hence a problem comes into being: in which way could the Second Language Acquisition be promoted comprehensibly? As we know, much work has been done on the role of input comprehension; no systematic study of output has been conducted until Swain's “Output Hypothesis”. There are two aspects of contexts that are important to the formulation of Merrill Swain's "Output Hypothesis". One is the dominant theoretical paradigm for second language acquisition research in the1980s: information processing theory. Another is the widespread growth of French immersion programs in Canada (Swain,2007).

In the study, with immersing Canadian students, Swain has shown that even students have received abundant comprehensible input in French and are somewhat fluent in the language; they have still not required grammatical competence in the language. Students' syntactical errors in French testifies that the target language grammatical system has not been fully acquired. This can account for why comprehensible input is not the only factor in second language acquisition. Swain suggests that output is the missing factor and calls the concept: comprehensible output, which has come to be called the Output Hypothesis.

To understand Output Hypothesis, we should know what output it is. What is output? It does not get a specific conceptual definition from Swain other than some synonyms, for example, there are” producing language”, (Swain, 1995) "producing the target language" (ibid) "using the language" and "speaking or writing”(Swain,1995). It seems that output in Swain's term is dynamic, not only the language produced by learners but also the activity of learners' producing the language. Now let's move on the definition of Output Hypothesis. Swain put it as the need for a learner to be pushed toward the delivery of a message that is not only conveyed, but that is conveyed precisely, coherently and appropriately (Swain, 1985). That is to say, the output of learners can force them to acquire language.

\subsection{Three Functions of the $\mathrm{OH}$}

When producing the target language, many learners may practice more about it, so it could enhance fluency. However, we know that fluency and accuracy are different dimensions of language performance. Although practice may enhance fluency, it does not necessarily improve accuracy (Ellis 1998).

Guided by the conception that output can be an effective way to learn second language, Swain has found three functions of the output. They are noticing function, hypothesis testing function and metalinguistic function. She believes that the improvement of our students' output abilities can help to notice the gap between the English learners and the native speakers by expressing themselves out, test whether they have made some mistakes in the course of communication and recall whether the sentences and language use are consistence with the fixed expression pattern of source language(Swain, 1995).According to Swain, comprehensible output can advance the accuracy and fluency of language use because the learners can realize their mistakes and then correct it guided by teachers. Thanks to the feedback, the learners learn some new language. Here is another evidence. Mackey's (2002) study has an excellent example of hypothesis testing from a learner's perspective. The learner is reacting to an interaction episode in which she, another learner and a teacher are involved. We always could hear the learner ask the other person involved, like "Can I say it that way?" or "I don't know if that's right, is it?" Therefore, the feedback from the opposite side is meaningful for learner because learner could be informed of his words right or be understood. If learners were not testing hypothesizes, then changes in their output would not be expected following feedback. In this sense, output is more a way of learning than an approach to expressing oneself. Obviously, Swain's OH still has great influence on the SLA teaching.

\subsection{The Historical Studies of $\mathrm{OH}$ on Teaching College English Writing}

In China, there are many studies concerning about output hypothesis. For example, Zhao Pei, a professor in Nanjing University of Science and Technology, did a questionnaire survey of 186 students in the university (63PHD students 
and 123 graduates). The survey confirmed the facilitating role of output in language learning and revealed some problems in the current English writing teaching in College. She concluded in the study that the output should be improved in the classroom. The teacher should encourage students to produce more language output in diversified forms and to increase interaction between students and the teachers in the process of language producing.

There is one empirical study on the impact of Swain's Output Hypothesis. It may have been made on the improvement of the college English writing in China. The paper is writtenby Zhao Ping from East China Shipbuilding Institute, with the title called The Implication of Swain's Output Hypothesis for the Teaching of College English Writing in China. To examine the three functions of output, Zhao did an experiment with 35 sophomores as subjects, for whom Zhao has 4 writing tasks, entitled respectively The Dictionary, Getting Rid of Bad Habits, Today's Higher Education, and An Unforgettable Thing. Via the study of all the compositions and the research on the writing process of two of the subjects, Zhao found evidence to support that in the process of learners' second language writing, output did perform its functions of both the noticing and the hypothesis-testing, but no apparent meta-linguistic function.

With the development of the Output Hypothesis in China, many English teachers in the college have applied the hypothesis to teach English writing.

\section{Methodology}

\subsection{Participants}

The selection of participants for this study took place at the very beginning of the 2017-18 school year. To address the research questions listed above, we set two criteria for choosing the participants: (1) students are all seniors in different classes from our Foreign Languages College;(2) teachers all have two years' experience or over two years of teaching writing class. The decision to select the subjects in this way was based on the fact that seniors have had writing class for one year; students from different classes could provide comprehensive information; teachers with teaching writing experience could make study result more valid.

On the basis of these criteria, we finally selected 20 students. Of all the participants, $60 \%(n=12)$ were female. The ages of the participants ranged from 20 to 21, with the mean being 20.8. Six teachers are all experienced writing teachers.

\subsection{Instruments}

\section{Semi-structured interview}

We conducted a semi-structured interview to gain an in-depth knowing of drawbacks of English writing class in the college. While conducting the interviews, the students were asked to answer three questions: (1) How do you like writing class?(2) Do you think writing classes in your college are good enough or not, if not, what are the reasons?(3) Can you propose some suggestions to make writing class more beneficial to students? The teachers were asked to three questions: (1) What are students' attitude toward your writing class?(2) What challenges do you think writing class is facing?(3) Can you make some suggestions to make writing class more beneficial to students?

\subsection{Data Collection and Analysis}

The students were asked to be interviewed on the weekend because they had a busier schedule at weekday. While on the weekend, they would not be bothered by other things. The teachers were interviewed after they have finished their teaching in one certain day. This would be more convenient because they did not live in the school. After we recorded all the conversations, we coded them into scripts, analyzed and clarified them. And the results would be showed in the next parts.

\section{Results and Discussion}

After we have analyzed all the materials, we found some problems existed in the present teaching of college English writing.

\subsection{Inadequate Attention and Application}

Although writing is one of the five basic skills in English learning, it does not get adequate attention in reality. Actually, according to students A: "When I was a freshman, there was no writing class, so in the first year, we did not pay any attention on it. In the second year, we had to take TEM4(Test For English Majors Grade 4), and this exam requires writing an essay. So in this year we took the writing classes. "And student B also said:” In this year, as a 
senior, there are not writing class anymore because we have finished TEM4. "Student E added:" Even though we have to take TEM8 in the next year, but we do not need to take writing class anymore."

Apart from inadequate attention on the writing class, there is another problem. The English writing curriculum in the college requires students the ability to write compositions of different styles. However, in our country, teachers and students usually focus on the writing of argumentative compositions which are likely to be useful for students' kinds of tests. Students have little chance to practice some applicable styles.

\subsection{Low Motivation and Interest}

Motivation is a very important aspect for improving English proficiency. Nevertheless, college students are lack of motivation of learning English. According to student C: "The reason why we do not write is probably that college English writing is lack of real-life application and we just do not want to write.” Student D also says:” We do not like writing and we seldom write English compositions unless our writing teacher asks us to write". And student F adds: "Our compositions are usually composed of fixed outline, fixed sentences patterns and fixed writing styles. Instead of expressing our true opinions, we usually recite others' compositions. Therefore, we do not have high motivation to improve our English writing ability and not interested in how to express our ideas."

\subsection{Inappropriate and Insufficient Feedback}

Teachers' feedback is quite important for students to improve their English writing. Student A says: "Our writing teacher asks us to write more compositions, which can give us more opportunities to practice our writing, and more opportunities to output our acknowledge. Unfortunately, due to the limited time and heavy teaching task, teachers do not have enough time to give clear feedback for students' work. As a matter of fact, we care the scores of compositions more than the feedback. "So in this way, students' writing output cannot be improved.

\section{Implication of $\mathrm{OH}$ on College English Writing}

As we know, SLA has arrived at a height we have never seen as with the closer communication in the intentional community, so how to promote the development of SLA is of great importance. Although certain improvement has been gained in some aspects, there are still problems in teaching college English writing at present. The problems have been discussed above and here are some suggestions on college English teaching:

\subsection{Raise the Awareness of the Importance of English writing}

From the previous interview, we can know that writing has not been drawn attention from college teachers who mainly focus on the aspects of input. Therefore, students majoring in English have not paid much attention to English writing. As a main form of output, It must be taken seriously and be practiced more frequently. Students should be given more chance to express themselves during the class-time, and to express what they know, not only when they are writing composition. In this process, knowledge and opinions that students cannot express well before will draw their notice and trigger their later improvement. What' more, detailed analysis of discourse should be added to the task of intensive reading to help students write and think. Teachers should also raise students' awareness of the importance of English output.

\subsection{Appropriate Feedback is Encouraged in Writing Class}

English writing assignments are usually made and then handed back to the teacher. During the process of writing, students usually play as also singers as they think, write and reread the feedback by themselves. They seldom communicate with other students, nor does the teachers give them chance to communicate and cooperate during the whole process of writing. When students communicate or cooperate with other students, they can both notice their output and test the hypothesis of what they think they know, which will improve their output by communicating again and again.

\section{Conclusions}

The OH proposes (Swain, 1985) that in order to increase learners' English proficiency, they need to generate output, i.e., produce language via speaking or writing and receive feedback on the comprehensibility of their output. Input is necessary, but not sufficient for language learning. Output is seen to be another essential part as it promotes fluency of language; pushes students to engage in syntactic processing of language; gives students opportunities to test their hypothesis. Therefore, output can improve learners' language proficiency, based on a few suggestions given by this thesis on teaching English writing class. In order to improve students' English writing ability, college teachers should give students more chances to output, more specifically, to write. What's more, types and patterns of writing 
assignments should be variable to raise students' motivation, interest, as well as the practical applicability of students' writing ability. Teachers' feedback is another important factor for improving students' writing, so the feedback should be clear, appropriate and sufficient.

\section{Acknowledgments}

Thanks for my supervisor and classmates. I am very appreciated for their helpful comments and suggestions on my study.

\section{References}

Ellis, R. (1988). The role of practice in classroom language learning. AILA Review, 5, 20-39.

Izumi, S. (2003). Comprehension and production processes in second language learning: In search of the psycholinguistic rationale of the output hypothesis. Applied Linguistics, 24(2), 168-196. https://doi.org/10.1093/applin/24.2.168

Jia Na. (2007). Output Hypothesis and College English Writing. LiaoNing Normal University, 26.

Krashen, S. D. (1985). The Input Hypothesis:Issues and Implications. London: Longman.

Krashen, S. D. (1998). Comprehension Output. System, 175-182. https://doi.org/10.1016/S0346-251X(98)00002-5

Li Ping. (2006). Twenty Years of Language Output Hypothesis: Review and Reflection. Foreign Languages and Their Teaching, 60-64.

Liu Chunyan. (2008). Language Output and Foreign Language Teaching. World Publishing Corporation, 132.

Swain, M. (1985). Communicative competence: Some roles of comprehensible input and comprehensible output in its development. MA: Newbury House, 36.

Swain, M. (1993). The Output Hypothesis: Just Speaking and Writing Aren't Enough. The Canadian Modern Language Review, 50(1), 158-164. https://doi.org/10.3138/cmlr.50.1.158

Swain, M. (1995). Three functions of output in SL learning. Principles \&Practice in Applied Linguistics. Oxford: OUP, 38.

Swain, M. (1997). The output hypothesis: Its history and its future. Foreign language teaching and research, 28.

Swain, M. (2000). The output hypothesis and beyond: Mediating acquisition through collaborative dialogue. Sociocultural theory and second language learning. Oxford: OUP, 40.

Wang Chuming., Niu Ruiying \& Zhen Xiaoxiang. (2003). Promoting Learning through Writing -- an Experiment of Teaching Reform of English Writing. Foreign language teaching and research, 3. 